\title{
Advanced oxidation protein products downregulate CYP1A2 and CYP3A4 expression and activity via the NF-KB-mediated signaling pathway in vitro and in vivo
}

\author{
Tianrong Xun ${ }^{1} \cdot{\text { Zhufen } \operatorname{Lin}^{1} \cdot \text { Xiaokang Wang }}^{1} \cdot$ Xia Zhan ${ }^{1} \cdot$ Haixing Feng ${ }^{2} \cdot$ Danna Gan ${ }^{1} \cdot$ Xixiao Yang ${ }^{1,2}$ \\ Received: 27 October 2020 / Revised: 22 April 2021 / Accepted: 26 April 2021 / Published online: 24 May 2021 \\ (c) The Author(s), under exclusive licence to United States and Canadian Academy of Pathology 2021. This article is published with open access
}

\begin{abstract}
Uremic toxin accumulation is one possible reason for alterations in hepatic drug metabolism in patients with chronic kidney disease (CKD). However, the types of uremic toxins and underlying mechanisms are poorly understood. In this study, we report the role of advanced oxidation protein products (AOPPs), a modified protein uremic toxin, in the downregulation of cytochromes P450 1A2 (CYP1A2) and P450 3A4 (CYP3A4) expression levels and activities. We found that AOPP accumulation in plasma in a rat CKD model was associated with decreased protein levels of CYP1A2 and CYP3A4. CYP1A2 and CYP3A4 metabolites (acetaminophen and 6 $\beta$-hydroxytestosterone, respectively,) in liver microsomes were also significantly decreased. In human hepatocytes, AOPPs significantly decreased CYP1A2 and CYP3A4 protein levels in a dose- and time-dependent manner and downregulated their activities; however, bovine serum albumin (BSA), a synthetic precursor of AOPPs, had no effect on these parameters. The effect of AOPPs was associated with upregulation of $\mathrm{p}-\mathrm{IKK} \alpha / \beta$, $\mathrm{p}-\mathrm{I} \kappa \mathrm{B} \alpha, \mathrm{p}-\mathrm{NF}-\kappa \mathrm{B}$, and inflammatory cytokines protein levels and increases in $\mathrm{p}-\mathrm{IKK} \alpha / \beta / \mathrm{IKK} \alpha, \mathrm{p}-\mathrm{I} \kappa \mathrm{B} \alpha / \mathrm{I} \kappa \mathrm{B} \alpha$, and $\mathrm{p}-\mathrm{NF}-\kappa \mathrm{B} /$ NF-kB phosphorylation ratios. Further, NF-kB pathway inhibitors BAY-117082 and PDTC abolished the downregulatory effects of AOPPs. These findings suggest that AOPPs downregulate CYP1A2 and CYP3A4 expression and activities by increasing inflammatory cytokine production and stimulating NF- $\mathrm{KB}-$ mediated signaling. Protein uremic toxins, such as AOPPs, may modify the nonrenal clearance of drugs in patients with CKD by influencing metabolic enzymes.
\end{abstract}

\section{Introduction}

Patients with chronic kidney disease (CKD) require a mean of 14.2 concurrent drugs to manage their complications and associated comorbidities, and overdose or underdose errors account for $20.4 \%$ of all medical problems in these patients [1]. Dosing alterations for many renally cleared drugs in CKD patients have been well characterized; however, hepatic metabolism is also altered in CKD [2]. Drug pharmacokinetics are the result of the coordinated action of

These authors contributed equally: Tianrong Xun, Zhufen Lin

Xixiao Yang

yaxx@smu.edu.cn

1 Department of Pharmacy, Shenzhen Hospital, Southern Medical University, Shenzhen, China

2 Department of Pharmacy, Nanfang Hospital, Southern Medical University, Guangzhou, China various drug-metabolizing enzymes, including cytochromes P450 (CYPs), and this coordinated action is highly altered in CKD [3]. These alterations are poorly understood, but numerous animal studies have indicated that CKD and decreased hepatic metabolism (including metabolism involving CYPs) are closely associated [4]. Moreover, CYPs activity is reduced in patients with CKD $[5,6]$.

CYP3A4 is the main CYP3A family member and is responsible for the metabolism of $\sim 50 \%$ of clinically used drugs. Many of these drugs are used to treat CKD or its comorbidities [7, 8]. Alterations in the pharmacokinetics of CYP1A2-metabolized drugs have been reported in CKD [3]. Studies on uremic serum collected from patients with end-stage renal disease (ESRD) have indicated that ESRD decreases the protein expression and activities of the major xenobiotic-metabolizing CYP1A and CYP3A families in rat hepatocytes $[9,10]$. Furthermore, intravenously administering a CYP3A4 substrate led to 6-fold higher systemic exposure in patients with ESRD compared to healthy controls [11]. Thus, the activities of CYP1A2 and CYP3A4 are decreased in CKD and are expected to have significant 
clinical implications, with altered drug pharmacokinetics and increased adverse drug events in patients with CKD. However, specific CKD-related factors that downregulate the activities of CYP1A2 and CYP3A4 have not been identified. Uremic toxins, which accumulate in the body in patients with CKD, may be involved [12, 13]. Nevertheless, the underlying molecular mechanism remains unknown.

AOPPs are a family of dityrosine-containing protein products that have been detected in the plasma of chronic uremic patients [14]. AOPPs are novel oxidative stress biomarkers and proinflammatory mediators and are related to oxidation-associated diseases [15]. AOPPs are highaffinity ligands for RAGE and CD36 and increase inflammatory cytokine (IL- 6 and TNF- $\alpha$ ) production and oxidantdependent activation of the NF- $\kappa \mathrm{B}$ signaling pathway in human chondrocytes $[16,17]$. AOPPs have been studied extensively from their structural and pharmacokinetic properties to their clinical significance.

The NF- $\kappa B$ signaling pathway plays a key role in the regulation of the inflammatory cytokine production and NF$\kappa B$ binds to CYP450 promoter regions to regulate CYP450 transcription and translation [18]. Activation of the NF- $\mathrm{kB}$ pathway is mediated by an increase in the phosphorylation of IKK and interaction with the inhibitory protein inhibitor $\kappa \mathrm{B}$ (ІкB) that binds to NF- $\kappa \mathrm{B}$ and sequesters it in the cytoplasm. Upon stimulation with exogenous substances, $\mathrm{I} \kappa \mathrm{B}$ is phosphorylated by I $\mathrm{KB}$ kinases and then degraded by the proteasome. This prevents I $\mathrm{KB}$ from sequestering NF$\kappa \mathrm{B}$ in the cytoplasm and leads to NK- $\mathrm{KB}$ translocation to the nucleus and activation or silencing of its target genes $[19,20]$. We hypothesized that AOPPs increase inflammatory cytokine production and activate the NF- $\mathrm{kB}$ signaling pathway, thereby regulating drug metabolism.

The objective of this study was to determine whether AOPPs can modify the expression of CYP1A2 and CYP3A4 and whether inflammatory cytokines and the NF$\mathrm{\kappa B}$ signaling pathway are involved in this process. To address this issue, we utilized a rat model of CKD to investigate the effect of AOPPs on CYP1A2 and CYP3A4 expression and activities in the liver. Thereafter, AOPPsmediated downregulation of CYP1A2 and CYP3A4 was investigated in HepG2 and L-02 cells. Finally, we suggest a molecular mechanism by which AOPPs downregulate CYP1A2 and CYP3A4 expression and activity.

\section{Materials and methods}

\section{Chemicals and reagents}

BAY-117082, pyrrolidine dithiocarbamate (PDTC), 4',6diamidino-2-phenylindole (DAPI) and bovine serum albumin (BSA) were purchased from Sigma-Aldrich (St. Louis,
MO, USA). Clorox was purchased from Macklin (Shanghai, China). Polyvinylidene fluoride (PVDF) membranes and a western blot detection system were purchased from Millipore (Darmstadt, Germany). Primary antibodies against CYP1A2 (DF3565), CYP3A4 (DF7001), histone H3 (AF0863), and GAPDH (AF7021) were purchased from Affinity Biosciences (California, USA). Primary antibodies

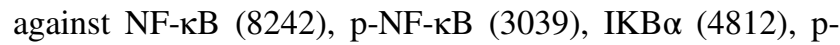
$\operatorname{IKB} \alpha$ (5209), IKK $\alpha$ (2682), p-IKK $\alpha / \beta$ (2697), and horseradish peroxidase-conjugated goat anti-mouse $(7076 \mathrm{~S})$ and goat anti-rabbit (7074 S) IgG were purchased from Cell Signaling Technology (Beverly, MA, USA). Tris-buffered saline with Tween 20 (TBST), antibody dilution buffer, and a pNF-кB-luc reporter plasmid were purchased from Beyotime (Shanghai, China).

\section{Preparation of AOPPs}

AOPPs were prepared in vitro as described previously [21]. Briefly, $20 \mathrm{mg} / \mathrm{ml} \mathrm{BSA}$ solution was combined with $40 \mathrm{mmol} / \mathrm{L}$ Clorox at a molar ratio of 1:140 for $30 \mathrm{~min}$ at room temperature protected from light. The samples were then dialyzed overnight against phosphate-buffered saline (PBS) to remove the free Clorox. Endotoxin levels in AOPP solutions were determined using an Amebocyte lysate assay kit (T-125; Zhanjiang, China). BSA dissolved in PBS was used as control.

\section{Animal model}

All animal studies were approved by the institutional Animal Experiment Committee of the Southern Medical University (Guangzhou, China). A total of 39 male Sprague-Dawley rats (160-200 g) were obtained from the Southern Medical University Animal Experiment Center (Guangzhou, China). The rats were treated according to a two-step procedure as described previously [22]. Briefly, the rats underwent five-sixths nephrectomy $(5 / 6 \mathrm{nx} ; n=21$ (3 later excluded due to surgery-related death) or sham operation (sham; $n=18$ ). Two weeks later, the $5 / 6 \mathrm{nx}$ and sham rats were randomized into subgroups (groups 1-3; 5/6 $\mathrm{nx}$, and sham groups $4-6 ; n=6$ per group). The rats in received intraperitoneal injections as follows once every other day for 8 weeks: (1) PBS (groups 1 and 4), (2) unmodified BSA (30 mg/kg, groups 2 and 5), and (3) AOPPs (30 mg/kg, groups 3 and 6). After 8 weeks, the rats were anesthetized with $3 \%$ pentobarbital sodium (v/v), and plasma samples were collected. The left kidney, the liver and the intestine were collected in liquid nitrogen.

\section{AOPPs concentration determination}

The concentration of AOPPs in the rat plasma was determined by spectral analysis as described previously [14]. 
Aliquots of $200 \mu \mathrm{l}$ of chloramine-T for calibration $(0-100 \mu \mathrm{mol}), 200 \mu \mathrm{l}$ of serum samples (diluted 1:5 in PBS), and $200 \mu \mathrm{l}$ of PBS as a blank control were placed in a 96well plate. Subsequently, $10 \mu \mathrm{l}$ of $1.16 \mathrm{M}$ potassium iodide and $20 \mu \mathrm{l}$ of acetic acid were added to each well. The absorbance of the reaction system at $340 \mathrm{~nm}$ was immediately measured. The AOPPs concentration was expressed as micromoles of chloramine-T equivalents per liter. The AOPPs concentration divided by the albumin level was regarded as the AOPPs level.

\section{Western blotting}

Cultured HepG2 and L-02 cells or frozen rat liver tissue samples were lysed with radioimmunoprecipitation assay (RIPA) lysis buffer containing protease inhibitors. The cytoplasmic and nuclear proteins were extracted with a nuclear and cytoplasmic protein extraction kit (KGP150; KeyGEN BioTECH, Jiangsu, China) according to the manufacturer's instructions. Equal amounts of protein were separated by sodium dodecyl sulfate polyacrylamide gel electrophoresis (PAGE) using 10\% acrylamide gels and then transferred to polyvinylidene fluoride (PVDF) membranes. The membranes were incubated with the following primary antibodies overnight at $4{ }^{\circ} \mathrm{C}$ : CYP1A2 (1:500), CYP3A4 (1:500), GAPDH (1:1000), NF-кB (1:1000), pNF-кB (1:1000), IKB $\alpha$ (1:1000), p-IKB $\alpha$ (1:1000), IKK $\alpha$ (1:1000), p-IKK $\alpha / \beta$ (1:1000), and histone H3 (1:1000; used as a reference antibody for nuclear proteins). The membranes were washed with TBST and incubated with horseradish peroxidase (HRP)-conjugated goat anti-rabbit $\operatorname{IgG}$ $(1: 3,000)$ or goat anti-mouse $\operatorname{IgG}(1: 3000)$ for $1 \mathrm{~h}$ at room temperature. The signals were visualized using enhanced chemiluminescence (ECL) detection, and a densitometric analysis was performed using imaging software. The protein levels were normalized to GAPDH or histone H3.

\section{Hepatic microsome isolation}

Hepatic microsomes were isolated by standard differential centrifugation procedures as previously described with a minor modification [23]. In brief, liver tissue was perfused with prechilled buffer comprising $1.5 \mathrm{mM}$ EDTA, $1 \mathrm{mM}$ DTT, $8 \mathrm{mM} \mathrm{KH}_{2} \mathrm{PO}_{4}, 0.28 \mathrm{mM}$ PMSF, and $5.6 \mathrm{mM}$ $\mathrm{Na}_{2} \mathrm{HPO}_{4}$. Thereafter, the collected tissue was shredded and homogenized in $50 \mathrm{mM}$ buffer $(\mathrm{pH}=7.4)$ comprising 1 $\mathrm{mM}$ EDTA, $0.28 \mathrm{mM}$ PMSF, and $250 \mathrm{mM}$ sucrose. The mixture was centrifuged at $12,000 \times \mathrm{g}$ and $4{ }^{\circ} \mathrm{C}$ for $15 \mathrm{~min}$ and the sediment was discarded. Next, the supernatant was centrifuged at $35,000 \times \mathrm{g}$ and $4{ }^{\circ} \mathrm{C}$ for $1 \mathrm{~h}$. The microsomes were resuspended in $250 \mathrm{mM}$ sucrose and the mixture was immediately stored at $-80^{\circ} \mathrm{C}$. The concentration of hepatic microsomes was determined using a bicinchoninic acid
(BCA) protein assay kit (KGSK4051; KeyGEN BioTECH, Jiangsu, China).

\section{Metabolism of CYP1A2 and CYP3A4 substrates}

The metabolic activities of CYP1A2 and CYP3A4 in hepatic microsomes was determined using specific probe substrates. Phenacetin was used as a probe for CYP1A2 [24] and testosterone was used as a probe for CYP3A4 [25]. Briefly, microsomes $(0.4 \mathrm{mg} / \mathrm{ml})$ were mixed on ice with 50 $\mathrm{mM}$ buffer $(\mathrm{pH}=7.4)$ comprising $1.5 \mathrm{mM}$ EDTA, $1 \mathrm{mM}$ DTT, $8 \mathrm{mM} \mathrm{KH}_{2} \mathrm{PO}_{4}, 0.28 \mathrm{mM}$ PMSF, and $5.6 \mathrm{mM}$ $\mathrm{Na}_{2} \mathrm{HPO}_{4}$, substrate, and a NADPH-generating system in a final incubation volume of $250 \mu \mathrm{l}$. The mixture was incubated in a shaking water bath at $37^{\circ} \mathrm{C}$ for $30 \mathrm{~min}$. The reaction was terminated by adding $200 \mu \mathrm{l}$ of cold methanol and the mixture was centrifuged at $15,000 \times \mathrm{g}$ for $30 \mathrm{~min}$. The supernatant was collected in a glass injection bottle.

Acetaminophen and 63-hydroxytestosterone was assessed by high-performance liquid chromatography (HPLC) system (Shimadzu, Japan) with an Eclipse Plus C18 column ( $5 \mu \mathrm{m}, 4.6 \times 250 \mathrm{~mm}$; Agilent). A sample volume of $20 \mu \mathrm{l}$ was injected into the column. The sample rack and column were maintained at $30^{\circ} \mathrm{C}$ and the flow rate was maintained at $0.75 \mathrm{ml} / \mathrm{min}$. Mobile phase A was HPLC-grade water with $0.1 \%(\mathrm{v} / \mathrm{v})$ formic acid, and mobile phase B was $100 \%$ acetonitrile. An ultraviolet detector was used to detect acetaminophen $(257 \mathrm{~nm})$ and $6 \beta$-hydroxytestosterone $(245 \mathrm{~nm})$. The quantification of acetaminophen and $6 \beta-$ hydroxytestosterone was based on the peak area.

\section{Immunofluorescence staining}

Immunofluorescence staining was performed using an NF- $\mathrm{kB}$ activation and nuclear translocation assay kit (SN368; Beyotime) according to the manufacturer's instructions with minor modifications. In brief, fixed cells were blocked with a sealing fluid for $1 \mathrm{~h}$ at room temperature. The cells were then incubated with rabbit anti-NF-kB antibody overnight at $4{ }^{\circ} \mathrm{C}$. After incubation with Cy5-conjugated anti-rabbit IgG for $1 \mathrm{~h}$, the nuclei were stained with DAPI $(1 \mu \mathrm{g} / \mathrm{ml})$. Fluorescent signals were captured with an FluoView FV10i self-contained confocal laser scanning microscope (Olympus, USA).

\section{Transient transfection and reporter gene assay}

A total of $0.5 \mu \mathrm{g}$ of pNF-kB-luc reporter plasmid or the equivalent amount of a control plasmid (D2206; Beyotime) was transfected into cells using Lipofectamine 3000 reagent (1741089; Life Technologies, Waltham, MA, USA) according to the manufacturer's protocol. After transfection for $24 \mathrm{~h}$, the cells were treated with AOPPs or without AOPPs (CON). Thereafter, cell lysis was carried out using 
reporter lysis buffer (RG055M; Beyotime). The cell extract was mixed with a luciferase substrate and the luciferase activity was immediately determined using a luminometer microplate reader (Spectrometer MD5; XYZ, USA).

\section{Enzyme linked immunosorbent assay (ELISA)}

After coculture with AOPPs, the concentrations of proinflammatory cytokines were measured in supernatants prepared using plasma or macrophages from the rats subjected to various treatments. The levels of TNF- $\alpha$ and IL- 6 in the supernatants were detected using ELISA kits (RA20035 and RA20607; Bio-Swamp, China) according to the manufacturer's instructions.

\section{Statistical analysis}

The data are expressed as mean \pm standard deviation (SD). A Michaelis-Menten model was used to fit the data regarding phenacetin and testosterone metabolite formation. The statistical analyses were performed in GraphPad Prism software (GraphPad 5.0 Software, USA). The data were analyzed using Student's $t$ test or one-way analysis of variance (ANOVA), with the least significant difference test being used as the post-hoc test. The data were also analyzed using three-factor ANOVA. Differences were considered statistically significant at $p<0.05$.

\section{Results}

\section{AOPPs administration increased AOPPs accumulation in plasma}

In the CKD model, renal function parameters, including plasma creatinine (Cr) (Fig. 1A), blood urea nitrogen (BUN) (Fig. 1B) and AOPPs (Fig. 1C), were increased by 1.9-fold, 7.3-fold, and 2.0-fold compared with those in the sham group. After AOPPs administration, AOPPs were increased in the sham and 5/6 nx groups (Fig. 1D), 2.6-fold and 1.6-fold compared with that in the PBS group. These data suggest that AOPPs administration increases AOPPs accumulation in the plasma.

\section{AOPPs downregulated CYP1A2 and CYP3A4 protein levels in the intestine, kidney, and liver}

In the sham group, treatment with AOPPs reduced CYP1A2 protein levels in the intestine, kidney, and liver by $44 \%$, $28 \%$, and 35\%; CYP3A4 protein levels in the intestine, kidney, and liver were reduced by $46 \%, 42 \%$, and $40 \%$, respectively (Fig. 2A). In the $5 / 6 \mathrm{nx}$ group treated with AOPPs, CYP1A2 protein levels in the intestine, kidney, and liver were reduced by 59\%, 63\%, and $66 \%$ and CYP3A4 protein levels were reduced by $71 \%, 71 \%$, and $68 \%$, respectively, compared with those in the PBS or BSA groups (Fig. 2B).

\section{AOPPs downregulated the activities of CYP1A2 and CYP3A4 in the liver}

The activities of CYP1A2 (Fig. 2E) and CYP3A4 (Fig. 2F) in the liver microsomes were evaluated using phenacetin and testosterone, respectively. After treatment with AOPPs, the $\mathrm{V}_{\max }$ values for acetaminophen in the sham and 5/6 nx groups were reduced by $57 \%$ and $49 \%$ and the $\mathrm{K}_{\mathrm{m}}$ values were reduced by $52 \%$ and $64 \%$, respectively. The values of

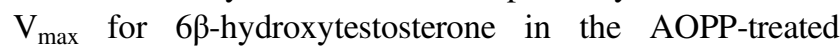
sham and $5 / 6 \mathrm{nx}$ rats were reduced by $31 \%$ and $43 \%$, respectively; the values of $\mathrm{K}_{\mathrm{m}}$ were reduced by $27 \%$ and $42 \%$, respectively, compared with those in the PBS or BSA groups.

\section{AOPPs downregulated CYP1A2 and CYP3A4 protein levels in HepG2 and L-02 cells}

CYP1A2 and CYP3A4 protein levels in HepG2 and L-02 cells were gradually decreased concomitant to an increase in the AOPPs concentrations (Fig. 3A). After treatment with $100 \mu \mathrm{g} / \mathrm{ml}$ AOPPs, CYP1A2 protein levels in HepG2 and L02 cells were reduced by $28 \%$ and $49 \%$ and the CYP3A4 levels were reduced by $25 \%$ and $23 \%$, respectively. After treatment with $200 \mu \mathrm{g} / \mathrm{ml}$ AOPP, CYP1A2 protein levels in HepG2 and L- 02 cells were reduced by $53 \%$ and $60 \%$ and the CYP3A4 levels were reduced by $57 \%$ and $44 \%$, respectively. CYP1A2 and CYP3A4 protein levels in HepG2 and L-02 cells were gradually decreased over time (Fig. 3B). After treatment with $200 \mu \mathrm{g} / \mathrm{ml}$ AOPPs for $24 \mathrm{~h}$, CYP1A2 protein levels in HepG2 and L-02 cells were reduced by $61 \%$ and $49 \%$ and the CYP3A4 levels were reduced by $52 \%$ and $33 \%$, respectively. In summary, CYP1A2 and CYP3A4 levels were lower when the concentrations of AOPPs exceeded $100 \mu \mathrm{g} / \mathrm{ml}$ or when the incubation time reached $24 \mathrm{~h}$.

\section{AOPPs downregulated CYP1A2 and CYP3A4 activities in the liver microsomes}

AOPPs inhibited the production of acetaminophen (Fig. 3E) and 6 6 -hydroxytestosterone (Fig. 3F) in the rat liver microsomes in a dose-dependent manner. After treatment with $100 \mu \mathrm{g} / \mathrm{ml}$ AOPPs, the $\mathrm{V}_{\max }$ values for acetaminophen and 6 $\beta$-hydroxytestosterone in the microsomes were reduced by $29 \%$ and $21 \%$; however, the $\mathrm{K}_{\mathrm{m}}$ values were increased by 6.1 -fold and 2.9-fold, respectively. After $200 \mu \mathrm{g} / \mathrm{ml}$ AOPP treatment, the $\mathrm{V}_{\max }$ values were reduced 
Fig. 1 AOPPs administration increased AOPPs

accumulation in the plasma. Kidney function of $5 / 6 \mathrm{nx}$ rats was assessed based on $\mathrm{Cr}(\mathbf{A})$ and BUN (B), which indicated reduced renal function. Plasma AOPPs concentration was increased in 5/6 $\mathrm{nx}$ rats $(\mathbf{C})$. After AOPPs administration, the plasma AOPPs concentration in the sham and $5 / 6 \mathrm{nx}$ rats increased (D). The results are shown as a scatter plot and each point represents one rat. $* p<$ 0.05 compared with the sham group; ${ }^{\#} p<0.05$ compared with the PBS group.
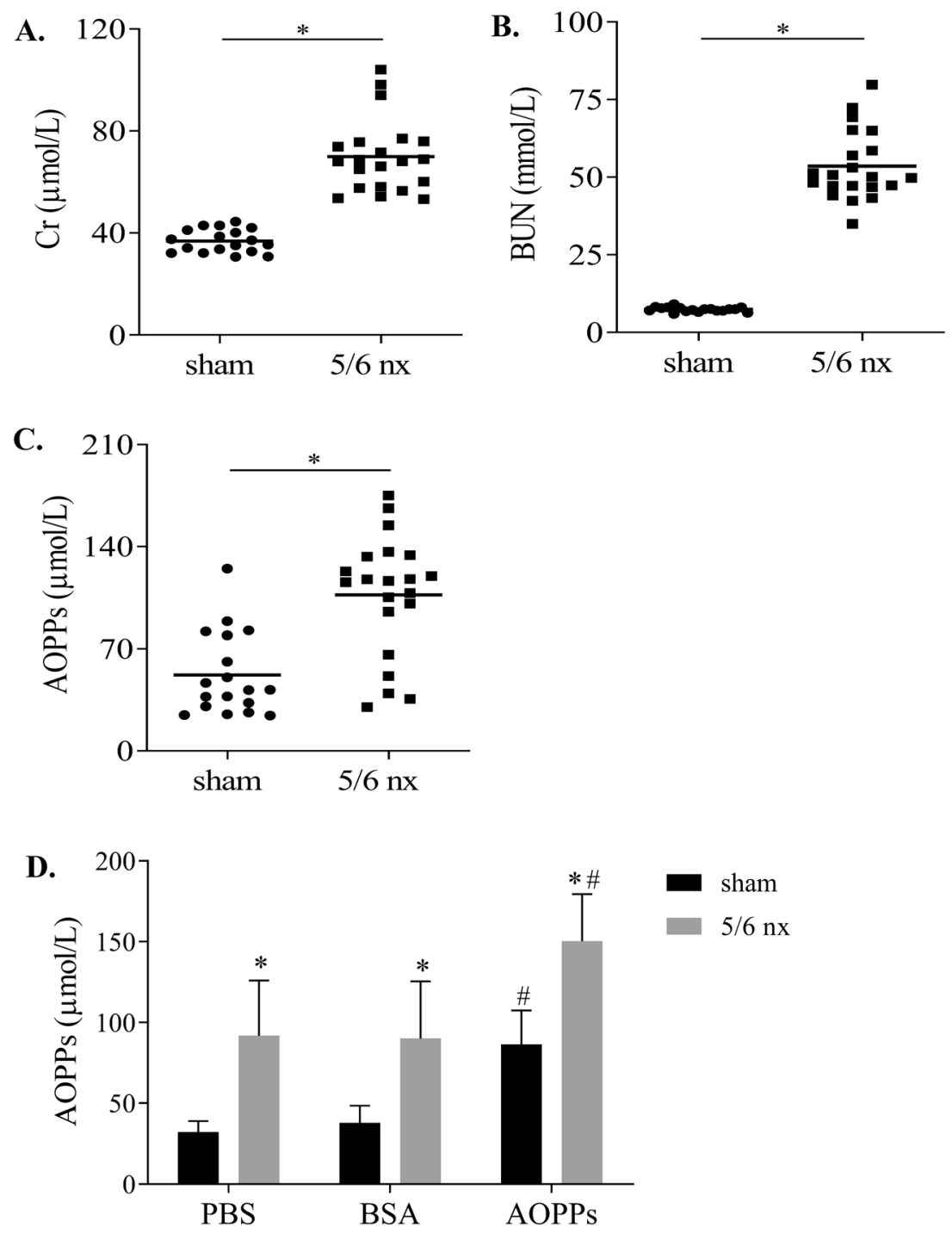

by $52 \%$ and $41 \%$; however, the $\mathrm{K}_{\mathrm{m}}$ values were increased by 6.8 -fold and 3.0 -fold, respectively.

\section{AOPPs activated the IKK/IKB/NF-KB pathway in vitro and in vivo}

To investigate the mechanism responsible for the decrease in CYP1A2 and CYP3A4, we investigated the links between

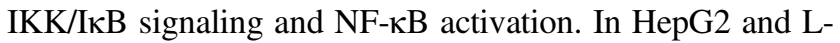
02 cells (Fig. 4A), AOPPs significantly and dosedependently induced IKK/I $\mathrm{KB} / \mathrm{NF}-\kappa \mathrm{B}$ phosphorylation compared to the CON group. BSA had no effect compared to the CON group. We next examined the effect of AOPPs on the protein expression of $\mathrm{IKK} / \mathrm{I} \kappa \mathrm{B} / \mathrm{NF}-\kappa \mathrm{B}$ in the liver of rats. AOPPs significantly increased $\mathrm{p}-\mathrm{IKK} \alpha / \beta, \mathrm{p}-\mathrm{I \kappa B} \alpha$, and p-NF- $\kappa B$ protein levels in the sham and $5 / 6 \mathrm{nx}$ rats and significantly increased the phosphorylation ratio of $\mathrm{p}-\mathrm{IKK} \alpha /$

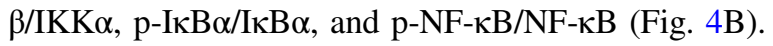

\section{AOPPs-induced nuclear translocation of NF-KB}

We assayed the nuclear translocation of the NF- $\mathrm{kB}$ protein induced by AOPPs using a confocal microscope. NF- $\mathrm{kB}$ protein in the nucleus was increased in HepG2 (Fig. 5A) and L-02 (Fig. 5B) cells, with almost no increase in the control group. NF- $\mathrm{\kappa B}$ protein was detected in the cytoplasmic and nuclear protein fractions of HepG2 and L-02 cells, and NF- $\mathrm{kB}$ protein levels were slightly increased in the cytoplasm and significantly increased in the nucleus in a dose-dependent manner (Fig. 5C).

\section{AOPPs downregulated CYP1A2 and CYP3A4 expression via the NF-KB pathway}

To gain an insight into NF- $\mathrm{BB}$ activation, we examined the effects of AOPPs on a luciferase reporter construct containing the functional gene followed by the coding sequence 

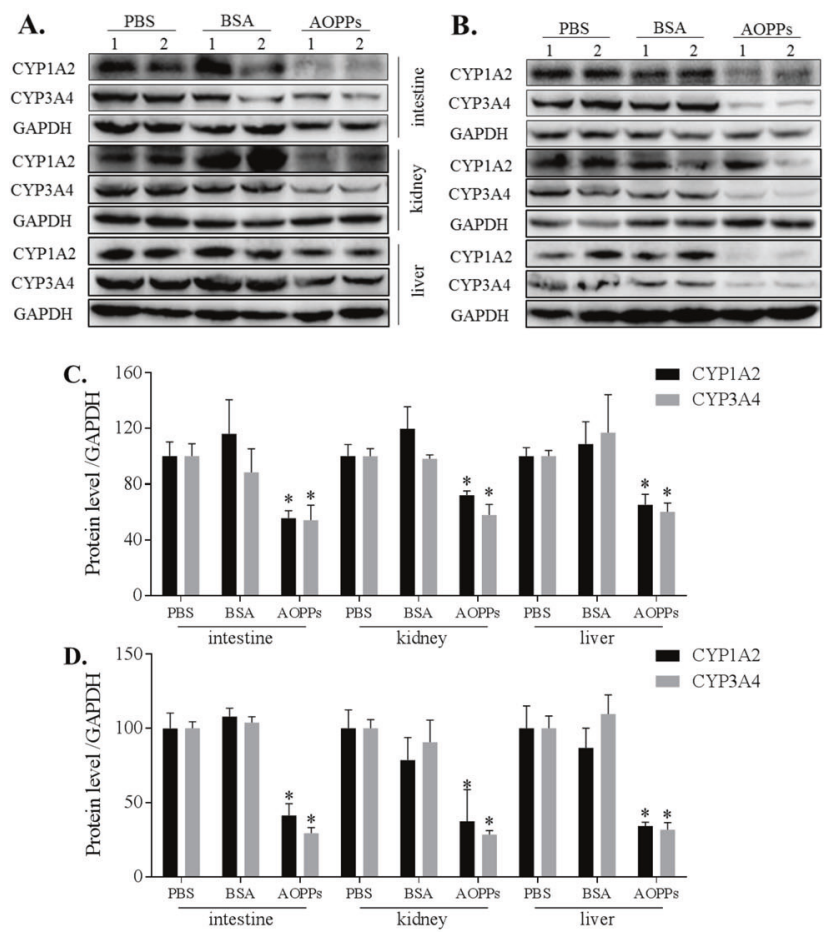

Fig. 2 AOPPs downregulated the protein expression and activities of CYP1A2 and CYP3A4 in vivo. Total protein was extracted from the intestine, kidney, and liver in the sham (A) and 5/6 $\mathrm{nx}$ groups (B), and the protein expression of CYP1A2 and CYP3A4 in a whole-cell lysate was evaluated by western blotting. Proteins expression levels were quantified by ImageJ software $(\mathbf{C}, \mathbf{D})$. Each experiment was performed with a different isolate. Michaelis-Menten plots of acetaminophen $(\mathbf{E})$ and 6 6 -hydroxytestosterone $(\mathbf{F})$ were constructed after

of the firefly luciferase gene. Similar to lipopolysaccharide, AOPPs can dose-dependently induce NF- $\mathrm{KB}$ pathway activation in HepG2 and L-02 cells compared with the CON groups of the corresponding cells, thus increasing the transcription and translation of the luciferase reporter gene (Fig. 6A). Inhibitors of the NF-kB pathway, $5 \mu \mathrm{M}$ BAY117082 (Fig. 6B) and $25 \mu \mathrm{M}$ PDTC (Fig. 6C), effectively ameliorated the decrease in the CYP1A2 and CYP3A4 protein expression levels induced by AOPPs. The protein expression levels in the BAY-117082 (Fig. 6D) and PDTC (Fig. 6E) groups were quantified by the ImageJ software. These data suggest that AOPPs downregulate CYP1A2 and CYP3A4 expression via the NF- $\mathrm{BB}$ pathway.

\section{AOPPs downregulated CYP1A2 and CYP3A4 expression via the inflammatory cytokine pathway}

Initially, the effect of AOPPs administration on the expression of TNF- $\alpha$ and IL- 6 in the rat plasma and macrophages was examined by ELISA. After AOPPs administration, the concentrations of TNF- $\alpha$ in the plasma of the sham and 5/6 nx rats were increased by 6.0 -fold and 1.3fold and the levels of IL- 6 were increased by 4.6 -fold and
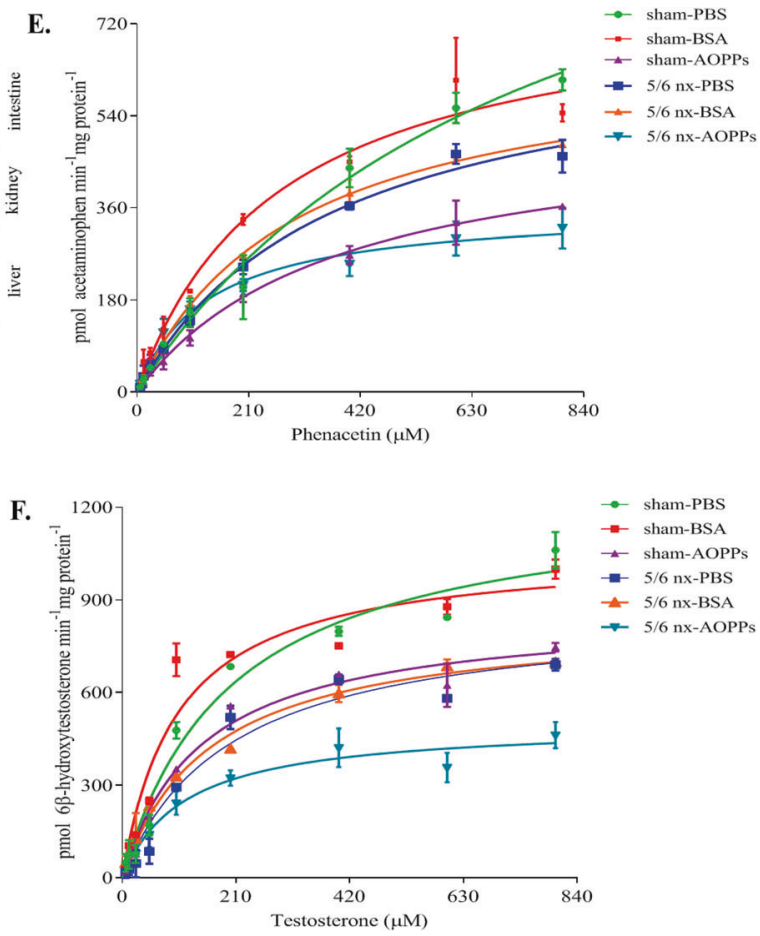

incubation of liver microsomes (extracted from the liver tissues in the sham and 5/6 nx groups) with NADPH and various concentrations of phenacetin or testosterone, respectively, which were used to evaluate the activities of CYP1A2 and CYP3A4, respectively. Each data point represents the mean of three replicates and the error bars represent standard error of the mean $(n=3)$. Data are presented as mean $\pm \mathrm{SD}$; $* p<0.05$ compared with the PBS group. Data were normalized to GAPDH.

1.4-fold, respectively (Fig. 7A). In rat macrophages, AOPPs increased the levels of IL-6 and TNF- $\alpha$ in a dose-dependent manner with no effect of BSA. The levels were significantly higher than that detected in the CON group (Fig. 7B). Next, we found that IL-6 treatment caused a dose-dependent decrease in the protein expression of CYP1A2 and CYP3A4 in HepG2 and L-02 cells (Fig. 7C), as did TNF- $\alpha$ treatment (Fig. 7D). The protein expression levels in the IL-6 (Fig. 7E) and TNF- $\alpha$ (Fig. 7F) groups were quantified by the ImageJ software. The data suggest that TNF- $\alpha$ and IL- 6 can directly influence the expression of CYP1A2 and CYP3A4 proteins.

\section{Discussion}

This study demonstrates that AOPPs mediate the downregulation of CYP1A2 and CYP3A4 in vitro and in vivo. An exogenous increase in the AOPP plasma concentration significantly increased TNF- $\alpha$ and IL- 6 release and reduced the expression and metabolic activities of CYP1A2 and CYP3A4 proteins in the liver. In human hepatocytes, purified AOPPs significantly reduced the protein expression of 


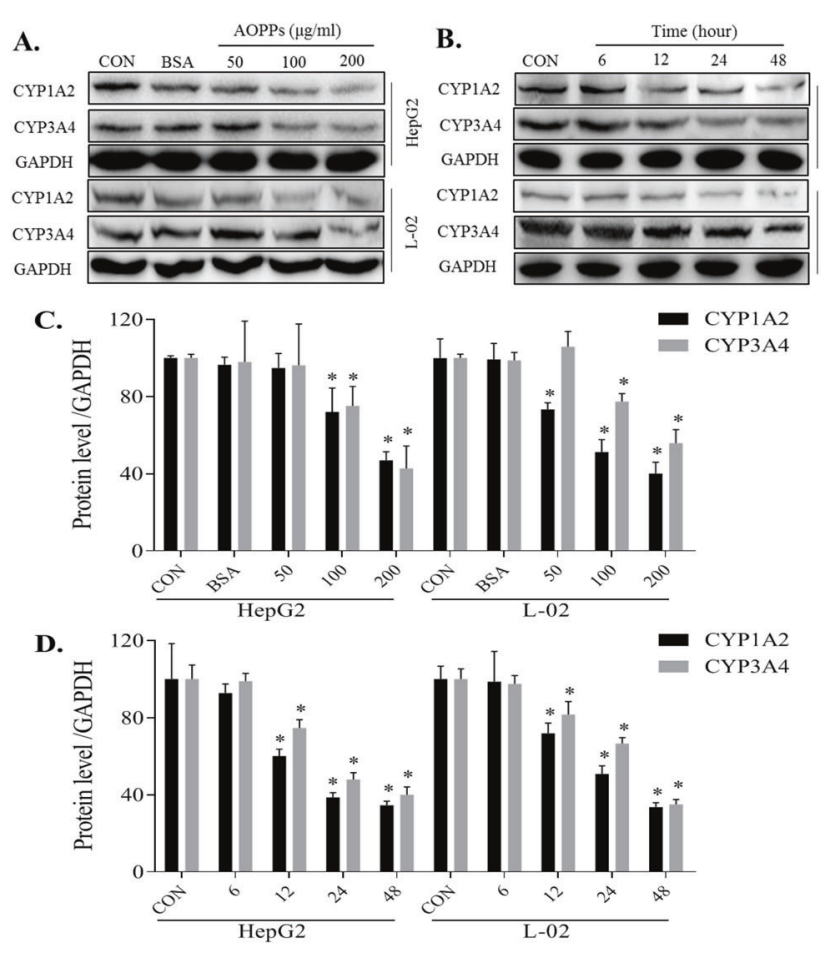

Fig. 3 AOPPs downregulated the protein expression and activities of CYP1A2 and CYP3A4 in vitro. HepG2 and L-02 cells were treated with the control medium (CON), BSA, or the indicated AOPPs concentration. AOPPs treatment decreased the protein expression of CYP1A2 and CYP3A4 in a dose- (A) and time-dependent manner (B). Protein expression levels were quantified by ImageJ software $(\mathbf{C}, \mathbf{D})$. Each experiment was performed with a different isolate. Microsomes

CYP1A2 and CYP3A4 by activating the relevant proteins in the NF- $\mathrm{KB}$ pathway. BAY-117082 and PDTC, inhibitors of the NF-kB pathway, significantly reversed the effect of AOPPs.

A number of studies have shown that CKD alters renal and nonrenal drug elimination; the accumulated uremic toxins and inflammatory cytokines may modulate metabolic enzymes either directly or by inhibiting protein expression [26]. New techniques to remove small-molecule or proteinbound uremic toxins from patients with CKD can still leave these patients with altered drug pharmacokinetics in response to certain drugs, and the pharmacokinetic parameters are difficult to assess [6]. To explore the effects of AOPPs in CKD, we used the 5/6 nx CKD model, in which the residual nephrons are characterized by elevated perfusion, filtration, and pressure, eventually leading to CKD. Markers of CKD are increased in this model by 8 weeks, such as serum creatinine, BUN and AOPPs (Fig. 1A-C). Elevated perfusion and filtration increase the effects of uremic toxins on the liver. However, the $5 / 6 \mathrm{nx}$ model can limit liver function changes caused by CKD, unlike other CKD models (e.g., the adenine model).

AOPPs, a new class of renal pathogenic mediators of CKD progression that gradually increase in the blood with
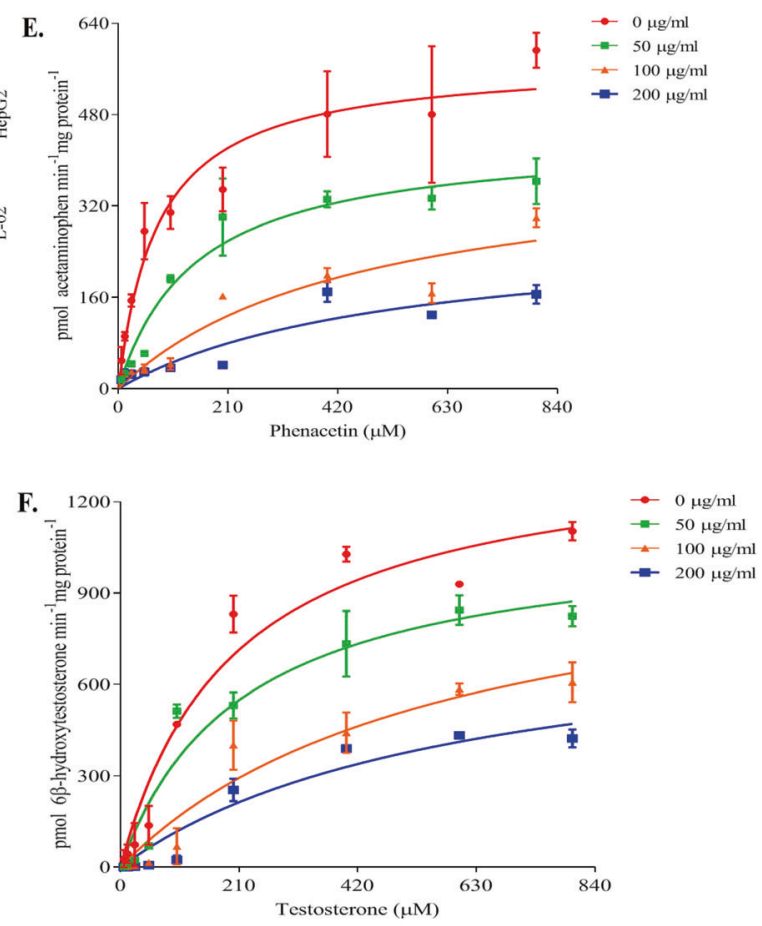

were treated with indicated concentration of AOPPs and the substrate. AOPPs dose-dependently decreased the activities of CYP1A2 (E) and CYP3A4 (F). Each data point represents the mean of three replicates and the error bars represent standard error of the mean $(n=3)$. Data are presented as mean $\pm \mathrm{SD} ;{ }^{*} p<0.05$ compared with the $\mathrm{CON}$ group. Data were normalized to GAPDH.

CKD progression, are dityrosine-containing crosslinking protein products formed during oxidative stress by reactions of plasma proteins with chlorinated oxidants [27]. AOPPs are primarily eliminated in the liver via the scavenger receptors in hepatic non-parenchymal cells and macrophages, and they are involved in liver disease progression via highly complex mechanisms [28]. Although several studies have investigated the profound effects of AOPPs regarding progressive liver function damage, there have only been a few studies on the potential mechanisms [29]. To the best of our knowledge, this study is the first to clarify that AOPPs mediate the downregulation of the expression and activities of CYP1A2 and CYP3A4 in the liver. The plasma AOPP concentration was significantly increased in the AOPPs-treated rats compared to the BSA- or PBStreated rats, regardless of whether the rats were in the sham or 5/6 nx group (Fig. 1D). The increase plasma levels of significantly decreased the protein expression of the metabolic enzymes CYP1A2 and CYP3A4 in the liver (Fig. 2A, B), and the metabolism of the probe substrates was significantly decreased (Fig. 2E, F). Thus, AOPPs can reduce CYP1A2 and CYP3A4 function in the liver and thereby influence the normal physiological function of the liver. 
Fig. 4 AOPPs activated the IKK/ІкB/NF-кB pathway in vitro and in vivo. $A O P P s$ increased the expression of $\mathrm{p}$ NF- $\kappa B, p-I K B ~ \alpha$, and $p-I K K \alpha / \beta$ in the total protein fraction of HepG2 and L-02 cells (A). AOPPs increased the expression of $\mathrm{p}-\mathrm{NF}-\kappa \mathrm{B}, \mathrm{p}-\mathrm{IKB} \alpha$, and $\mathrm{p}-$ IKK $\alpha / \beta$ in the liver tissues of the sham and 5/6 nx groups (B). Protein expression levels were quantified by ImageJ software (C, D). Each experiment was performed with a different isolate. Data are presented as mean $\pm \mathrm{SD} ; * p<0.05$ compared with the CON or PBS groups. Data were normalized to GAPDH.
A.

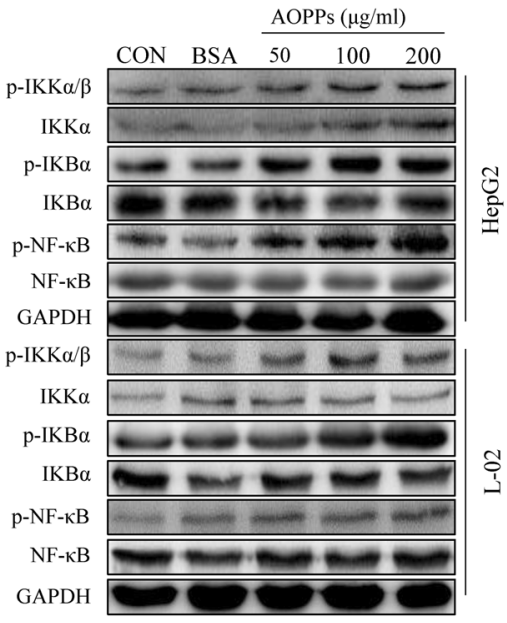

B.

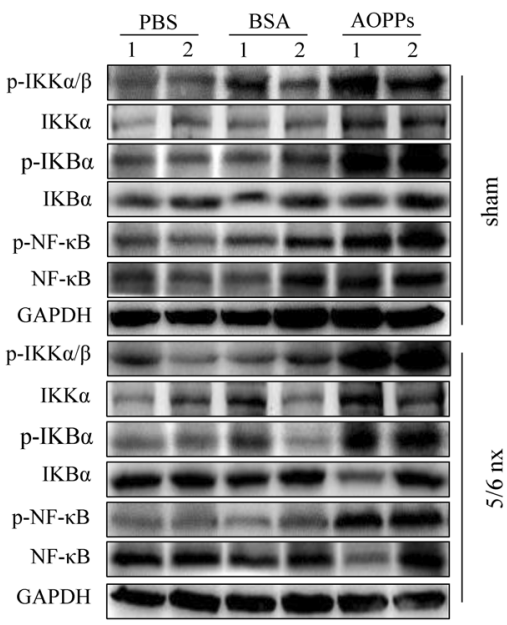

C.

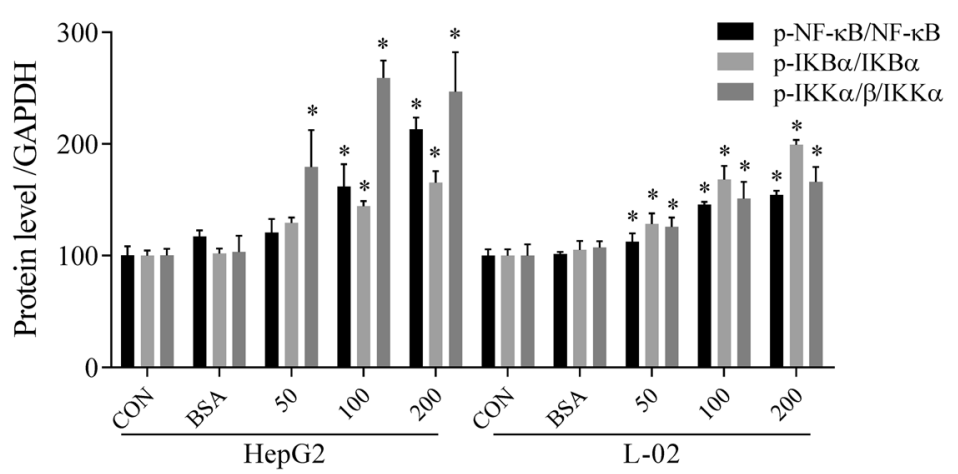

D.

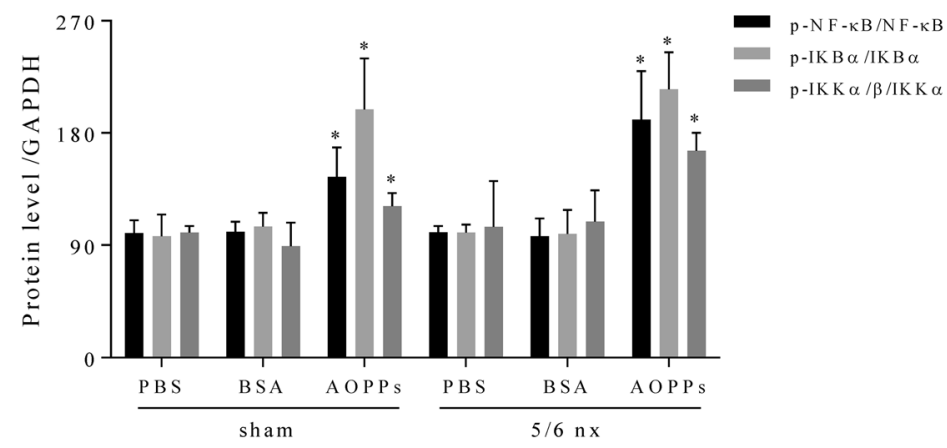

To further explore the independence of the effect of AOPPs, we cocultured the HepG2 and L-02 cell lines with or without AOPPs to confirm the accuracy of our results. HepG2 cells are transformed human hepatocellular cells that maintain the basic characteristics of hepatocytes and exhibit CYP1A2 and CYP3A4 expression. L-02 cells are normal human hepatocytes that also exhibit CYP1A2 and CYP3A4 expression and can be used as control cells to compare to cancer cells $[30,31]$. To confirm that the in vitro AOPPs experiments are relevant to the in vivo experiments, we performed dose- and time-dependent assays of AOPPs effects. In HepG2 or L-02 cells, AOPPs reduced the CYP1A2 and CYP3A4 protein expression in a dose(Fig. 3A) and time-dependent (Fig. 3B) manner. Liver microsomes are a common model for specific detection of enzyme metabolism in vivo [12]. In this study, the effects of AOPPs on the metabolism of phenacetin (Fig. 3E) and testosterone (Fig. 3F) were explored. Phenacetin is a specific substrate of CYP1A2 and its main metabolite is acetaminophen [24]. Testosterone is a specific substrate of CYP3A4 and its main metabolite is $6 \beta$-hydroxytestosterone [25]. Each compound specifically responds to changes in the activity of the corresponding metabolic enzyme $[13,32]$. The results of the CYP1A2 and CYP3A4 assays were similar to the in vivo data from rats. However, the marked increases in the $\mathrm{K}_{\mathrm{m}}$ values in the liver microsome reaction system may be related to the non-specific binding of AOPPs.

AOPPs can induce reactive oxygen species production and activate the NF-kB pathway to produce a series of 
Fig. 5 AOPPs-induced nuclear translocation of NF- $\mathrm{kB}$.

AOPPs increased nuclear translocation of NF- $\mathrm{KB}$ detected in the nuclear protein by laser confocal microscopy $(400 \times)$ in HepG2 (A) and L-02 cells (B). Cytoplasmic and nuclear protein expression levels of $\mathrm{NF}-\kappa \mathrm{B}$ were detected by western blotting $(\mathbf{C})$. Protein expression levels were quantified by ImageJ software (D). Each experiment was performed with a different isolate. Data are presented as mean $\pm \mathrm{SD} ; * p<0.05$ compared with the CON group. Data were normalized to GAPDH.

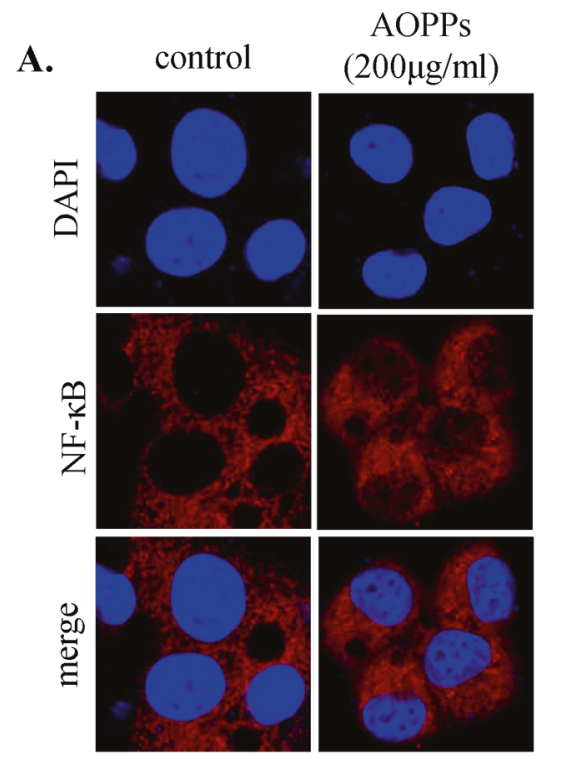

B.

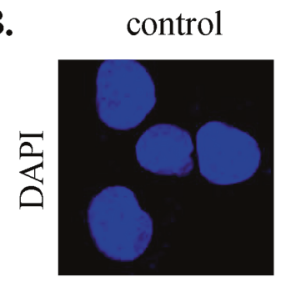

AOPPs $(200 \mu \mathrm{g} / \mathrm{ml})$

C.
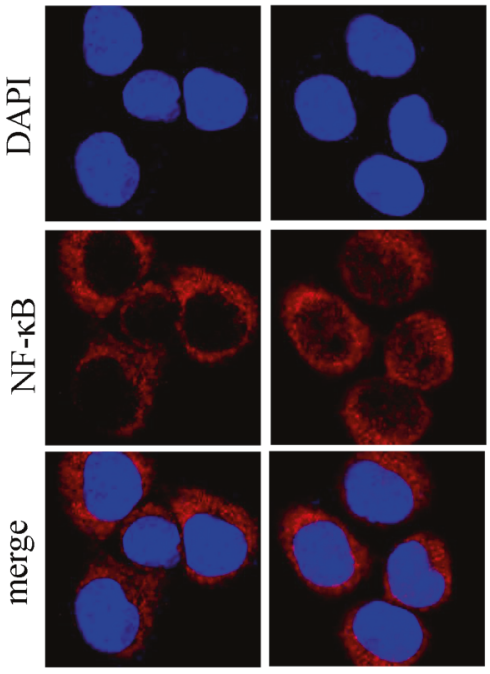

$\operatorname{AOPP}(\mu \mathrm{g} / \mathrm{ml})$
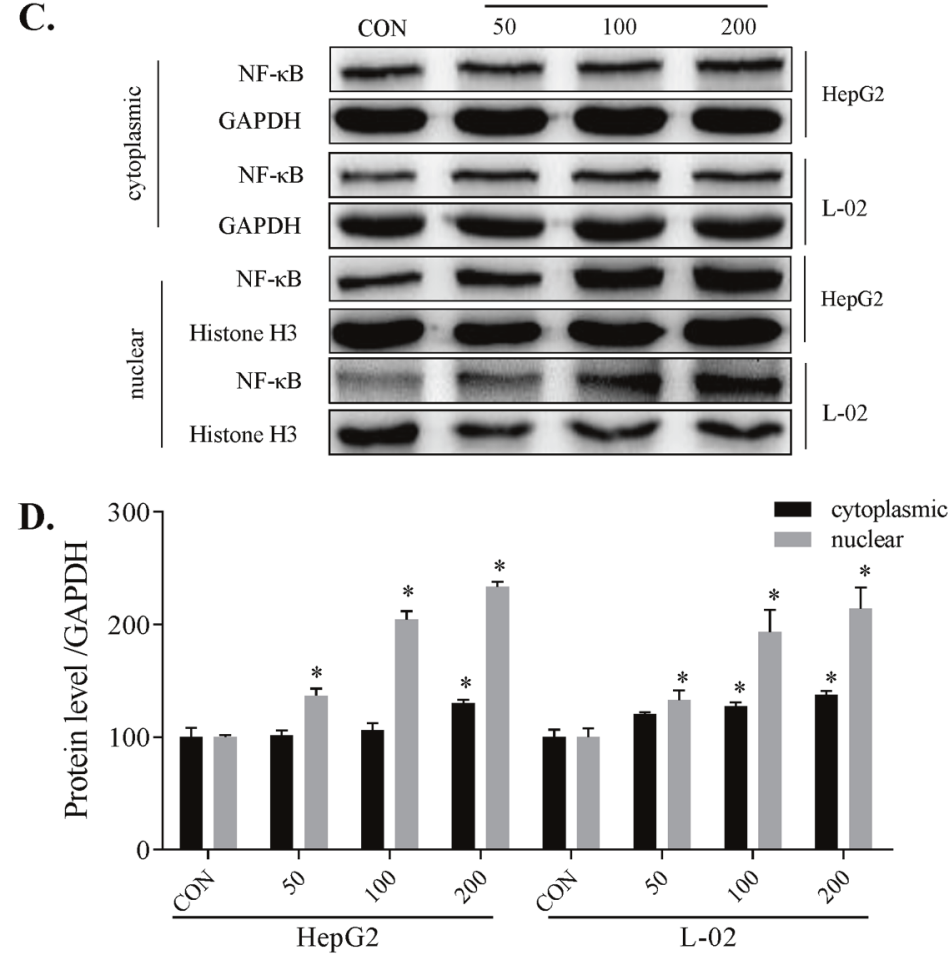

pathological processes $[17,33]$. NF- $\mathrm{BB}$ plays an important role in mediating the suppression of drug-metabolizing enzymes (DMEs). NF- $\mathrm{kB}$ activation has been associated with inflammatory conditions, oxidative stress, and crosstalk with several nuclear receptors that alter the expression and activity DMEs, thereby influencing drug metabolism [34]. However, it is unclear whether NF- $\mathrm{kB}$ activation is involved in the AOPPs-induced decrease in DMEs in the liver. To ascertain the mechanism, we assessed the NF- $\mathrm{KB}$ pathway and the associated upstream proteins, including $\mathrm{p}$ -
$\mathrm{IKK} \alpha / \beta, \mathrm{p}-\mathrm{I} \kappa \mathrm{B} \alpha$, and $\mathrm{p}-\mathrm{NF}-\kappa \mathrm{B}$. We found that these upstream proteins were significantly upregulated (Fig. 4). In AOPPs-treated cells transfected with a luciferase reporter plasmid, the luminescence intensity was significantly increased, indicating NF- $\mathrm{KB}$ pathway activation (Fig. 6A). At the same time, NF- $\mathrm{KB}$ protein was upregulated in the cytoplasm and nucleus, with increased NF- $\mathrm{KB}$ protein translocation to the nucleus (Fig. 5A-C). Furthermore, the AOPPs-induced downregulation of CYP1A2 and CYP3A4 expression was significantly ameliorated by BAY-117082 
Fig. 6 AOPPs downregulated CYP1A2 and CYP3A4 expression via the $\mathrm{NF}-\kappa \mathrm{B}$ pathway. NF- $\kappa B$-dependent firefly luciferase reporter gene was transfected into HepG2 or L-02 cells, and the reporter gene expression (A). HepG2 or L-02 cells were treated with AOPPs $(200 \mu \mathrm{g} / \mathrm{ml})$ for $48 \mathrm{~h}$ and cocultured with BAY-117082

(B) and PDTC (C) to restore the downregulated expression levels of CYP1A2 and CYP3A4.

Protein expression levels of CYP1A2 and CYP3A4 were quantified by ImageJ software (D, E). Each experiment was performed with a different isolate. Data are presented as mean $\pm \mathrm{SD} ; * p<0.05$ compared with the CON group; ${ }^{\#} p<0.05$ compared with the group without BAY-117082 or PDTC. Data were normalized to GAPDH.
A.

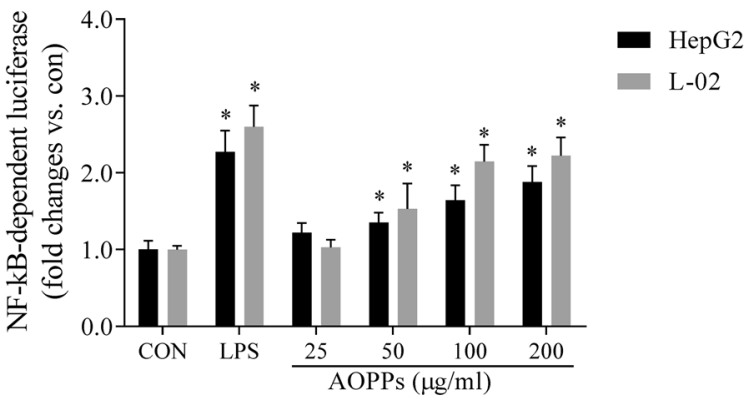

C. AOPPS

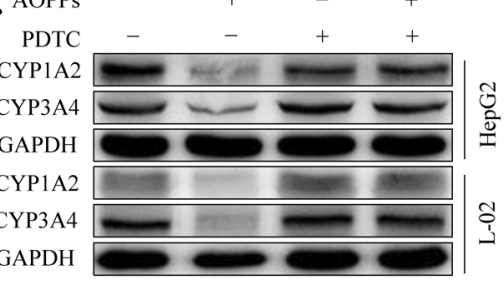

D.

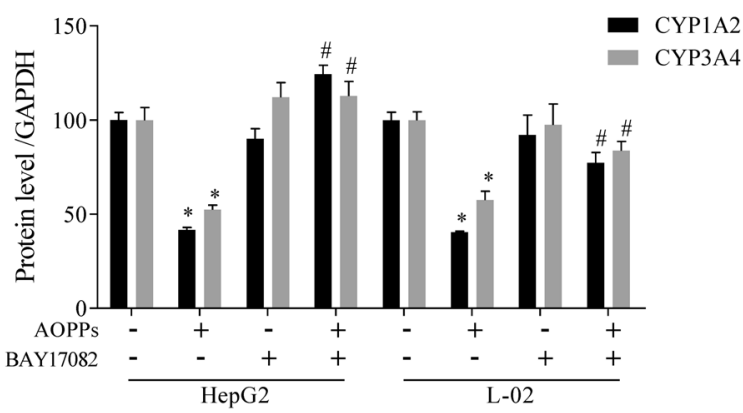

E.

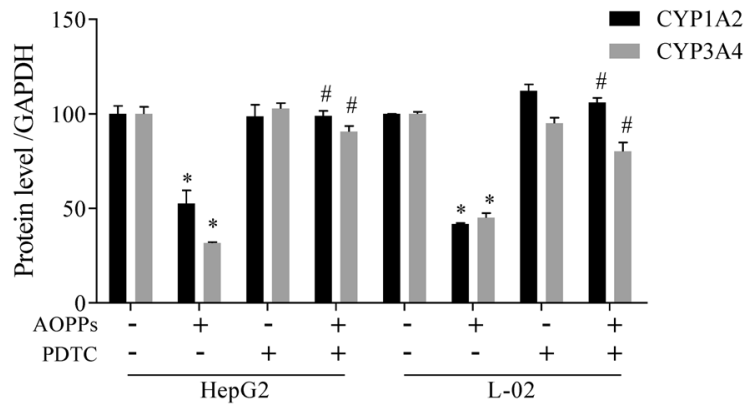

and PDTC. Thus, we showed that the inhibition of the NF$\kappa \mathrm{B}$ pathway prevented the decrease in the CYP1A2 and CYP3A4 expression. Research on the precise mechanism of AOPPs-induced downregulation of DMEs is ongoing.

We also evaluated whether inflammatory cytokines can directly influence the CYP1A2 and CYP3A4 expression and activity. AOPPs are a key factor in inflammatory diseases and can induce proinflammatory cytokine release $[16,35]$. The levels of multiple cytokines are increased in the plasma of patients with CKD [36]. IL- 6 and TNF- $\alpha$ influence DME expression in vitro and in vivo [37]. In our rat model, AOPPs increased the IL- 6 and TNF- $\alpha$ concentrations in the plasma (Fig. 7A), and they dosedependently increased the IL- 6 and TNF- $\alpha$ release in the rat macrophages (Fig. 7B). This result shows that AOPPs can upregulate the levels of IL- 6 and TNF- $\alpha$, which is consistent with previous findings. After treatment with various concentrations of IL- 6 or TNF- $\alpha$, the protein expression levels of CYP1A2 and CYP3A4 in HepG2 and L-02 (Fig. 7C, D) cells were dose-dependently downregulated. This result indirectly suggests that IL-6 and TNF$\alpha$ may participate in the AOPPs-related regulation of CYP1A2 and CYP3A4. However, the effects of IL-6 and 
Fig. 7 AOPPs downregulated

CYP1A2 and CYP3A4

expression via the

inflammatory cytokine

pathway. AOPPs increased the plasma concentrations of IL- 6

and TNF- $\alpha$ in the sham and 5/6

$\mathrm{nx}$ groups (A). AOPPs increased

the IL- 6 and TNF- $\alpha$

concentrations in rat

macrophages (B). HepG2 and L-

02 cells treated with various

concentrations of IL-6 (C) or

TNF- $\alpha$ (D) for $48 \mathrm{~h}$ exhibited

dose-dependent decreases in the

protein expression levels of

CYP1A2 and CYP3A4, as

evaluated by western blotting.

Protein expression levels of

CYP1A2 and CYP3A4 levels

were quantified by ImageJ

software $(\mathbf{E}, \mathbf{F})$. Each

experiment was performed with a different isolate. Data are presented as mean $\pm \mathrm{SD} ; * p<$ 0.05 compared with the CON group, ${ }^{\#} p<0.05$ compared with the sham group. Data were normalized to GAPDH.
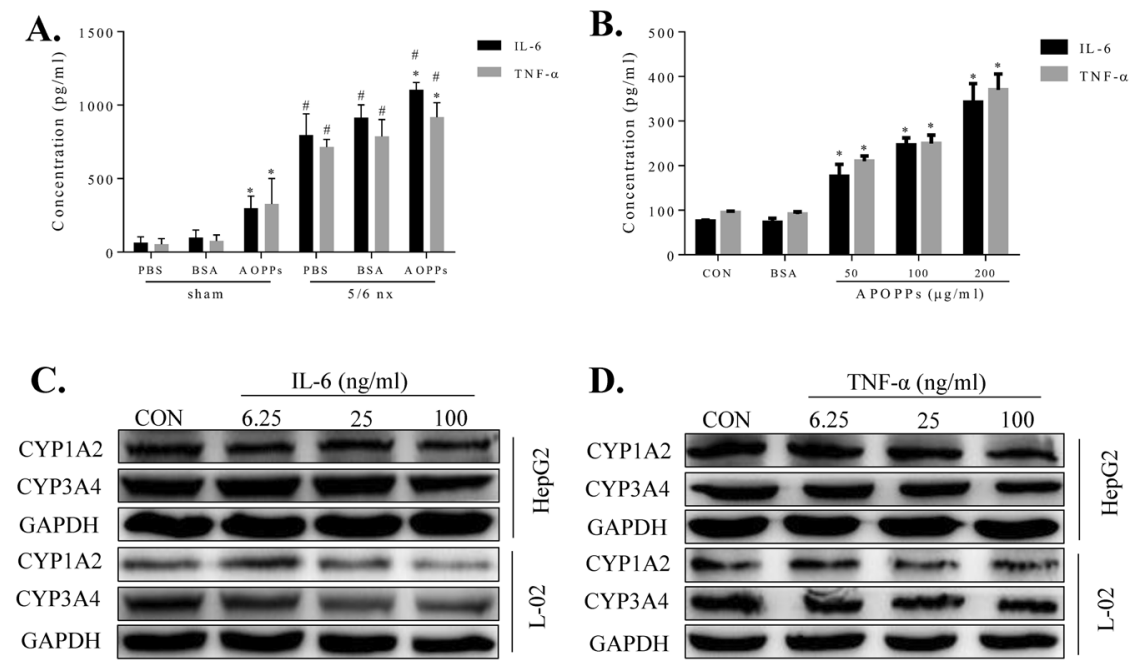

E.

F.

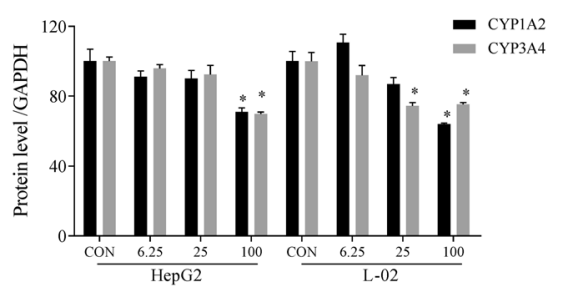

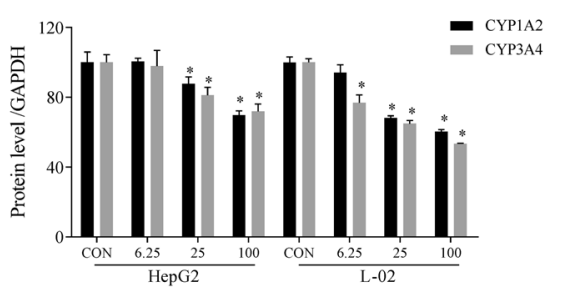

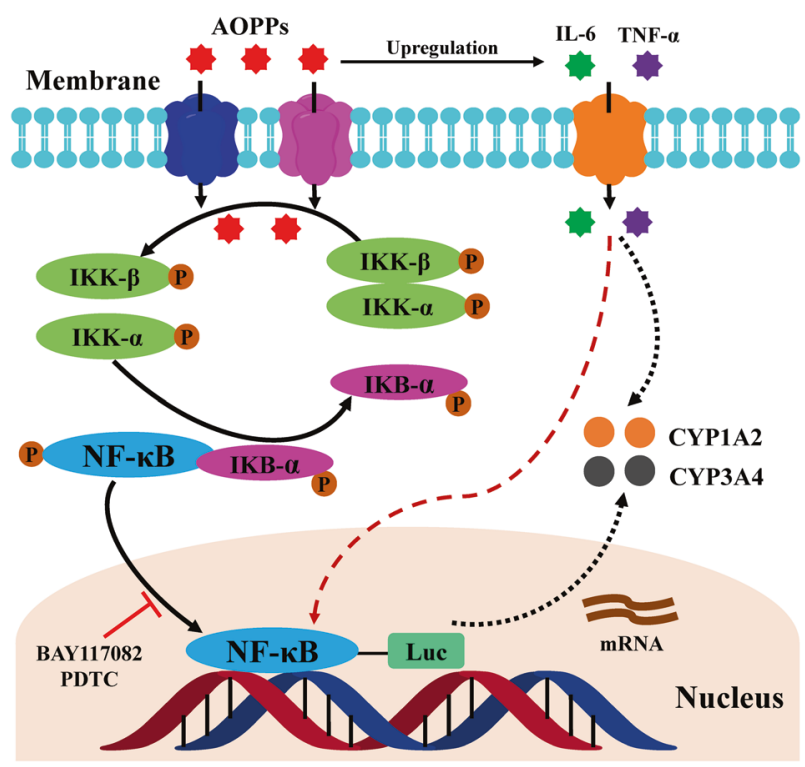

Fig. 8 Possible mechanism underlying the AOPPs-induced CYP1A2 and CYP3A4 downregulation. This study demonstrates that AOPPs significantly decrease the CYP1A2 and CYP3A4 expression and activities via direct activation of the $\mathrm{NF}-\mathrm{\kappa B}$ pathway and induction of nuclear translocation of $\mathrm{NF}-\kappa \mathrm{B}$ to inhibit the transcription and translation of CYP1A2 and CYP3A4. As inflammatory cytokines, IL- 6 and/or TNF- $\alpha$ may mediate this process.
TNF- $\alpha$ occur concurrently in vivo and our IL- 6 and TNF- $\alpha$ experiments were carried out separately in the in vitro models. Thus, additional experiments are needed to determine these specific interactions.

This study demonstrates that AOPPs significantly decrease the expression and activities of the CYP1A2 and CYP3A4 enzymes via the NF- $\mathrm{kB}$ signaling pathway, and IL-6 and/or TNF- $\alpha$ may mediate this process (Fig. 8). To the best of our knowledge, this is the first study to systematically evaluate the effect of AOPPs on hepatic drug metabolism using rat and cellular models. These results suggest that the metabolism and elimination of drugs that are metabolized by CYP1A2 or CYP3A4 may be altered by an increase in AOPPs, and additional studies are required to determine the relationships between AOPPs and DMEs. Prospective clinical studies are needed to investigate the extent of the contribution of AOPPs to the pharmacokinetic changes related to various drugs.

\section{Data availability}

All data and models during the study appear in the submitted article. The online version of this article (https://doi. org/10.1038/s41374-021-00610-9) contains supplementary material, which is available to authorized users. 
Author contributions Study design: XXY. Data acquisition: TRX, ZFL, XKW, XZ, HXF, and DNG. Data analysis and interpretation: TRX and ZFL. Paper writing: TRX and ZFL. Critical revision of the paper: XXY, TRX and ZFL. Obtained funding: XXY and TRX. All authors read and approved the final paper.

Funding This work was supported by research grants from the National Natural Science Foundation of China (NO. 81573681), Guangdong Science and Technology Program (NO. 2015B020211006), Shenzhen Foundation of Science and Technology (NO. JCYJ20190814112 205770), and Research Foundation of Shenzhen Hospital of Southern Medical University (NO. PY2021YM03).

\section{Compliance with ethical standards}

Ethics All animal studies were approved by the institutional Animal Experiment Committee of the Southern Medical University. we have provide the ethics statement in the chapter of animal model in method.

Conflict of interest The authors declare no competing interests.

Publisher's note Springer Nature remains neutral with regard to jurisdictional claims in published maps and institutional affiliations.

Open Access This article is licensed under a Creative Commons Attribution 4.0 International License, which permits use, sharing, adaptation, distribution and reproduction in any medium or format, as long as you give appropriate credit to the original author(s) and the source, provide a link to the Creative Commons license, and indicate if changes were made. The images or other third party material in this article are included in the article's Creative Commons license, unless indicated otherwise in a credit line to the material. If material is not included in the article's Creative Commons license and your intended use is not permitted by statutory regulation or exceeds the permitted use, you will need to obtain permission directly from the copyright holder. To view a copy of this license, visit http://creativecommons. org/licenses/by/4.0/.

\section{References}

1. Tonelli M, Wiebe N, Manns BJ, Klarenbach SW, James MT, Ravani $\mathrm{P}$, et al. Comparison of the complexity of patients seen by different medical subspecialists in a Universal Health Care System. JAMA Netw Open. 2018. https://doi.org/10.1001/jamanetw orkopen.2018.4852.

2. Lalande L, Charpiat B, Leboucher G, Tod M. Consequences of renal failure on non-renal clearance of drugs. Clin Pharmacokinet. 2014;53:521-32.

3. Ladda MA, Goralski KB. The effects of CKD on cytochrome P450-mediated drug metabolism. Adv Chronic Kidney Dis. 2016; 23:67-75.

4. Leblond F, Guévin C, Demers C, Pellerin I, Gascon-Barré M, Pichette V. Downregulation of hepatic cytochrome P450 in chronic renal failure. J Am Soc Nephrol. 2001;12:326-32.

5. Dowling TC, Briglia AE, Fink JC, Hanes DS, Light PD, Stackiewicz L, et al. Characterization of hepatic cytochrome p4503A activity in patients with end-stage renal disease. Clin Pharmacol Ther. 2003;73:427-34.

6. Yeung CK, Shen DD, Thummel KE, Himmelfarb J. Effects of chronic kidney disease and uremia on hepatic drug metabolism and transport. Kidney Int. 2014;85:522-8.
7. Furge LL, Guengerich FP. Cytochrome P450 enzymes in drug metabolism and chemical toxicology: an introduction. Biochem Mol Biol Educ. 2006;34:66-74.

8. Guengerich FP. Cytochrome p450 and chemical toxicology. Chem Res Toxicol. 2008;21:70-83.

9. Michaud J, Dubé P, Naud J, Leblond FA, Desbiens K, Bonnardeaux $\mathrm{A}$, et al. Effects of serum from patients with chronic renal failure on rat hepatic cytochrome P450. Br J Pharmacol. 2005;144:1067-77.

10. Michaud J, Nolin TD, Naud J, Dani M, Lafrance JP, Leblond FA, et al. Effect of hemodialysis on hepatic cytochrome P450 functional expression. J Pharmacol Sci. 2008;108:157-63.

11. Thomson BK, Nolin TD, Velenosi TJ, Feere DA, Knauer MJ, Asher LJ, et al. Effect of CKD and dialysis modality on exposure to drugs cleared by nonrenal mechanisms. Am J Kidney Dis. 2015;65:574-82.

12. Tsujimoto M, Higuchi K, Shima D, Yokota H, Furukubo T, Izumi $\mathrm{S}$, et al. Inhibitory effects of uraemic toxins 3-indoxyl sulfate and p-cresol on losartan metabolism in vitro. J Pharm Pharmacol. 2010;62:133-8.

13. Tsujimoto M, Sugimoto S, Nagatomo M, Furukubo T, Izumi S, Yamakawa T, et al. Possibility of decrease in CYP1A2 function in patients with end-stage renal disease. Ther Apher Dial. 2014;18: 174-80.

14. Witko-Sarsat V, Friedlander M, Capeillère-Blandin C, NguyenKhoa T, Nguyen AT, Zingraff J, et al. Advanced oxidation protein products as a novel marker of oxidative stress in uremia. Kidney Int. 1996;49:1304-13.

15. Selmeci L. Advanced oxidation protein products (AOPP): novel uremic toxins, or components of the non-enzymatic antioxidant system of the plasma proteome. Free Radic Res. 2011;45:1115-23.

16. Liao CR, Wang SN, Zhu SY, Wang YQ, Li ZZ, Liu ZY, et al. Advanced oxidation protein products increase TNF- $\alpha$ and IL-1 $\beta$ expression in chondrocytes via NADPH oxidase 4 and accelerate cartilage degeneration in osteoarthritis progression. Redox Biol. 2019. https://doi.org/10.1016/j.redox.2019.101306

17. Ye W, Zhong Z, Zhu S, Zheng S, Xiao J, Song S, et al. Advanced oxidation protein products induce catabolic effect through oxidant-dependent activation of NF- $\kappa$ B pathway in human chondrocyte. Int Immunopharmacol. 2016;39:149-57.

18. Saito T, Takahashi Y, Hashimoto H, Kamataki T. Novel transcriptional regulation of the human CYP3A7 gene by Sp1 and Sp3 through nuclear factor kappa B-like element. J Biol Chem. 2001;276:38010-22.

19. Ghosh S. Regulation of inducible gene expression by the transcription factor NF-kappaB. Immunol Res. 1999;19:183-9.

20. Karin M. How NF-kappaB is activated: the role of the IkappaB kinase (IKK) complex. Oncogene. 1999;18:6867-74.

21. Song S, Xiao X, Guo D, Mo L, Bu C, Ye W, et al. Protective effects of Paeoniflorin against AOPP-induced oxidative injury in HUVECs by blocking the ROS-HIF- $1 \alpha /$ VEGF pathway. Phytomedicine. 2017;34:115-26.

22. Mo L, Xiao X, Song S, Miao H, Liu S, Guo D, et al. Protective effect of Huang Gan formula in $5 / 6$ nephrectomized rats by depressing the Wnt/ $\beta$-catenin signaling pathway. Drug Des Devel Ther. 2015;9:2867-81.

23. Yan T, Gao S, Peng X, Shi J, Xie C, Li Q, et al. Significantly decreased and more variable expression of major CYPs and UGTs in liver microsomes prepared from HBV-positive human hepatocellular carcinoma and matched pericarcinomatous tissues determined using an isotope label-free UPLC-MS/MS method. Pharm Res. 2015;32:1141-57.

24. Murayama N, Soyama A, Saito Y, Nakajima Y, Komamura K, Ueno K, et al. Six novel nonsynonymous CYP1A2 gene polymorphisms: catalytic activities of the naturally occurring variant enzymes. J Pharmacol Exp Ther. 2004;308:300-6. 
25. Waxman DJ, Attisano C, Guengerich FP, Lapenson DP. Human liver microsomal steroid metabolism: identification of the major microsomal steroid hormone 6 beta-hydroxylase cytochrome P450 enzyme. Arch Biochem Biophys. 1988;263:424-36.

26. Momper JD, Venkataramanan R, Nolin TD. Nonrenal drug clearance in CKD: searching for the path less traveled. Adv Chronic Kidney Dis. 2010;17:384-91.

27. Cao W, Hou FF, Nie J. AOPPs and the progression of kidney disease. Kidney Int Suppl. 2014;4:102-6.

28. Iwao Y, Anraku M, Hiraike M, Kawai K, Nakajou K, Kai T, et al. The structural and pharmacokinetic properties of oxidized human serum albumin, advanced oxidation protein products (AOPP). Drug Metab Pharmacokinet. 2006;21:140-6.

29. Zhao Y, Zhang L, Ouyang X, Jiang Z, Xie Z, Fan L, et al. Advanced oxidation protein products play critical roles in liver diseases. Eur J Clin Invest. 2019. https://doi.org/10.1111/eci. 13098.

30. Huang Z, Wang M, Liu L, Peng J, Guo C, Chen X, et al. Transcriptional Repression of CYP3A4 by Increased miR-200a-3p and miR-150-5p Promotes Steatosis in vitro. Front Genet. 2019. https://doi.org/10.3389/fgene.2019.00484.

31. Strojny B, Sawosz E, Grodzik M, Jaworski S, Szczepaniak J, Sosnowska M, et al. Nanostructures of diamond, graphene oxide and graphite inhibit CYP1A2, CYP2D6 and CYP3A4 enzymes and downregulate their genes in liver cells. Int $\mathrm{J}$ Nanomedicine. 2018;13:8561-75.

32. McGraw J, Cherney M, Bichler K, Gerhardt A, Nauman M. The relative role of CYP3A4 and CYP3A5 in eplerenone metabolism. Toxicol Lett. 2019;315:9-13.

33. Wang JC, Zhao Y, Chen SJ, Long J, Jia QQ, Zhai JD, et al. AOPPs induce MCP-1 expression by increasing ROS-mediated activation of the NF- $\mathrm{KB}$ pathway in rat mesangial cells: inhibition by sesquiterpene lactones. Cell Physiol Biochem. 2013;32:1867-77.

34. Zordoky BN, El-Kadi AO. Role of NF-kappaB in the regulation of cytochrome P450 enzymes. Curr Drug Metab. 2009;10:164-78.

35. Zheng S, Zhong ZM, Qin S, Chen GX, Wu Q, Zeng JH, et al. Advanced oxidation protein products induce inflammatory response in fibroblast-like synoviocytes through NADPH oxidase -dependent activation of NF- $\kappa \mathrm{B}$. Cell Physiol Biochem. 2013;32:972-85.

36. Oettinger CW, Bland LA, Oliver JC, Arduino MJ, McAllister SK, Favero MS. The effect of uremia on tumor necrosis factor-alpha release after an in vitro whole-blood endotoxin challenge. J Am Soc Nephrol. 1994;4:1890-5.

37. Abdel-Razzak Z, Loyer P, Fautrel A, Gautier JC, Corcos L, Turlin $\mathrm{B}$, et al. Cytokines down-regulate expression of major cytochrome P-450 enzymes in adult human hepatocytes in primary culture. Mol Pharmacol. 1993;44:707-15. 